\title{
The Newest Sappho and Archaic Greek-Near Eastern Interactions
}

\author{
Kurt A. Raaflaub
}

The discovery of the "newest Sappho" is very exciting, and the attention the poem attracts is more than justified. ${ }^{1}$ Not least, it sheds most welcome additional light on the poet's relationship with her brother (or brothers). Given the general focus of the other chapters in this volume on literary, poetic, performative, and religious aspects, among others, it will perhaps be useful if I discuss some of the social, economic, and political background that underlies the poet's emotions in this segment of her work. In particular, I shall explore the Greek-Egyptian (or, more broadly, Greek-Near Eastern) connections suggested by the activities of Sappho's brother, Charaxos. In doing so, I will look at ways in which not only Sappho herself but also the other two super-famous Lesbian personalities of the time, Alcaeus and Pittacus, were affected by this "eastern connection."

\section{Sappho, Charaxos, Rhodopis/Doricha, and the Historical Significance of the "Newest Sappho"}

I begin with Sappho's brother, Charaxos. In his Egyptian logos, Herodotus says that some people attributed the pyramid of Mykerinos to the hetaira Rhodopis - quite falsely because she could not have afforded this monument and she lived during the time of Amasis, long after Mykerinos (2.134.1-3).

1 "Newest Sappho" according to this volume's title. I thank Toni Bierl and André Lardinois for accepting my contribution to this volume and for helpful comments and suggestions. Some parts of this chapter were written initially for a conference on Sappho, Alcaeus, and Pittacus that was in 2005 hosted by Apostolos Pierris on the island of Lesbos itself; unfortunately, the proceedings were never published. I offered a version of this revised paper at a workshop on 'Sappho: New Voices', held on Oct. 18, 2014 at Bard College under the direction of Lauren Curtis and Robert Cioffi. I thank them for organizing an exciting meeting, the Bard Classics Department and College for their splendid hospitality, and Deborah Boedeker for helpful suggestions.

(C) KURT A. RAAFLAUB, 2016 | DOI: 10.1163/9789004314832_007

This is an open access chapter distributed under the terms of the Creative Commons Attribution- 
She was by birth a Thracian, the slave of Iadmon ... of Samos, and ... [was] brought to Egypt by Xanthos the Samian, to follow her trade, and Charaxos of Mytilene, ... the brother of Sappho ..., paid a large sum to redeem her from slavery. Having in this way obtained her freedom, she remained in Egypt and succeeded by her great beauty in amassing a fortune which - for her-was considerable ... There is no sense in pretending she was excessively rich, for the tenth part of her property can be seen today by anyone who cares to go and look at it: for wishing to be remembered in Greece by some sort of temple-offering ..., she spent a tenth of her money on as many iron roasting-spits as it would buy, and sent them to Delphi. They still lie in a heap behind the altar which the Chians dedicated, opposite the actual shrine ... [Rhodopis became] so famous that every Greek was familiar with her name ... When Charaxos returned to Mytilene after purchasing Rhodopis' freedom, he was ridiculed by Sappho in one of her poems. So much, then, for Rhodopis.

2.135; trans. DE SÉLINCOURT and MARINCOLA

This intriguing story raises many questions. To the extent that we can answer them, Alan Lloyd, Leslie Kurke, and others have done so. ${ }^{2}$ Herodotus mentions her probably not just because her name came up in connection with the pyramid of Mykerinos but because in his "Guinness book of records" she held the top spot in some category, such as "most beautiful or famous courtesan." Why such interest in courtesans (hetairai) at all? Here I defer to Kurke, who places this passage in the larger context of Herodotus' use of women to unmask thoroughly 'the absurdities and pretensions of the elite system. ${ }^{4}$ Why a dedication in Delphi? Lots of people made dedications in sanctuaries after they had reached great success, made lots of money, or had been saved from disaster, and they did so not only in famous sanctuaries such as Delphi or Samos but also in local ones.

What seems more exceptional is a dedication in Delphi-perhaps the most prestigious sanctuary-by a low-status woman. We can imagine Rhodopis chuckling, particularly when we consider her particular choice of dedication: a

2 Lloyd (1975-1988) III.84-87; Kurke (1999) 175-178, 220-227, both with bibliography; see now also Nagy (2015a).

3 See further How and Wells (1912) 132; Lloyd (1975-1988) 3.84-85. Herodotus often draws attention to those who did something for the first time (see Lateiner [1989] 35-36) or who were the best or had achieved most in something (see, e.g., 4.152, mentioned below at n. 31).

4 Kurke (1999) 227. 
pile of roasting-spits. The significance of the latter is difficult for us to grasp. The gift may have intended to allude to ancient symbols of wealth and value (obeloi) and thus to boast with the wealth Rhodopis had acquired. ${ }^{5}$ Lloyd, accordingly, suggests the possibility that the spits were a "monetary" gift, but also, since spit-dedications were common at the time, that they "had simply become a standard way of testifying to one's devotion to the god or of leaving a personal memorial in a sacred spot'. Going one step further, Kurke plausibly suggests, Rhodopis (aided here by the historian) may have wanted to 'insert her gift completely into a sacral economy of sacrifice' and thus to place herself into the 'circumscribed, elite context' of this type of gift. ${ }^{6}$ Four and a half letters (KEROD) of an archaic inscription in Phocian script found in Delphi and dated by Jeffery to about 530 вСE have been restored to anethē]ke Rhod [opis, with scholarly applause. But initially the last letter was apparently read as a gamma rather than a delta, the stone was not found in situ, the date seems barely possible for Rhodopis, despite Jeffery's elaborate rationalization, and the restoration is far from certain. ${ }^{7}$ Ultimately, though, all this hardly matters: the dedication must have been placed on an inscribed base, and this is what Herodotus must have seen. ${ }^{8}$

If Rhodopis stood out as the best in her category, Charaxos owes his mention in Herodotus to her and not to his own achievements. The historian does not even tell us why he went to Naucratis, of which Mytilenaeans were cofounders and thus probably frequent visitors. ${ }^{9}$ The missing information, if it is more than an educated guess, is supplied by Strabo: he exported Greek wine to

On obeloi as symbols of a premonetary value-system, see Strøm (1992); von Reden (1997) 159-160.

$6 \quad$ Lloyd (1975-1988) 3.87; Kurke (1999) 223-224 with n. 4.

7 Jeffery (1990) 102 with pl. 12 fig. 7 ; see the reports in $B C H 78$ (1954) 133 with fig. 35 and the two reconstructions proposed by Makrokostas; ibid. 144 the initial reading as gamma; JHS 74 (1954) 158 with fig. 10; REG 68 (1955) 229 with reference to the find spot (in the wall of a chapel in the cemetery of Delphi) and perhaps slight reservations ('M. veut reconnaître'). Jeffery argues that the date of the inscription 'does not contradict other information about Rhodopis': 'that she flourished in the reign of Amasis (569-529) and-presumably after her retirement-left an outstanding offering to Delphi ... This may have been as much as $40-50$ years after Sappho's brother Charaxos had established her independently at Naucratis ..., which would permit a date of c. 530 or even a little later for the inscription'.

8 See also Ath. 13.596c who refers to the 'famous spits' of Rhodopis that, he says, were also mentioned by the comic poet Cratinus (the citation unfortunately is lost).

9 Hdt. 2.178.2; for evidence of Mytilenaean presence in Naucratis, see Lloyd (1975-1988) 3.226 . 
Egypt. ${ }^{10}$ This places him in the category of elite merchants, and here the record belonged to one Kolaios of Samos, about whom more will be said in a moment, and compared to whom Rhodopis' wealth and Charaxos' gains presumably were trivial. ${ }^{11}$

Nor, finally, do we know why exactly Sappho reacted so strongly to her brother's action. The word Herodotus uses, katekertomese, is usually translated as "she blamed, reproached, or abused him," but Denys Page takes it rather to mean "mocking, jeering, taunting." ${ }^{2}$ The poem the historian alludes to is lost. ${ }^{13}$ In what follows, I will first summarize my comments as I wrote them before the "newest Sappho" was known, ${ }^{14}$ and then assess changes brought about by the new find.

In the main surviving fragment that seems relevant here (fr. 5), Sappho (if it is Sappho: there is nothing that specifically identifies her) speaks of her brother (who is not named either) as absent and prays for his safe return and atonement for past wrongs (or errors, ossa ... ambrote), and that he may bring honor to his sister, after 'suffering cruel agony at the hands of ...' In the poem's continuation we hear about something that happened by 'the citizens' censure' or 'at a gathering of citizens', which he soon came to understand, and of an 'unendurable evil'. We do not know the nature of the brother's past wrongs nor who caused him cruel agony, nor again what this business with the citizens was, and who suffered what kind of unendurable evil. What is certain is that no woman is mentioned explicitly here. ${ }^{15}$ Another fragment (15) similarly expresses hope that a person (the name is not preserved, but the analogy seems to point to the same man) may 'atone for his past mistakes'. Aphrodite is asked to be 'very

$10 \quad$ Strabo 17.1.33; see Möller (2000) 55 .

11 Hdt. 4.152; see Möller (2000) 54-55 and below at n. 31.

12 Page (1955) 131; cf. 50 n. 2.

13 Page (1955) 5 .

14 See n. 1 above. I integrate here Obbink's new edition of fr. 5 (in ch. 1 of this volume) that, of course, was not yet known in 2005 .

15 Fr. 5: 'Revered daughters of the sea god, grant that / [my] brother may arrive here unharmed / and whatsoever he should desire in his mind / let that be completed. / And as much as he has previously done wrong (ossa ambrote) / grant atonement for it all; may he be a pleasure / to friends, and a harm to enemies - and may we / never have any. / And may he want to put his sister in a position / of greater honor, since before he was suffering cruel agony at the hands of ...' (trans. Obbink, ch. 1 in this volume; see his text and app. crit. with various proposed translations of the final section). Reading the poem in the form in which Obbink presents it, the brother's failings could have to do as much with politics as with a woman (see n. 47 below). 
harsh', and the speaker adds, 'may she, Doricha, not boast, telling how he came the second time to a longed-for love'. ${ }^{16}$ The woman who seems to be part of Sappho's brother's problem (if the poem is about these two), is possibly mentioned in three other fragments as well $(3,7$, and 9), but in all these cases she is called Doricha rather than Rhodopis: was this a different woman or a different name for the same? ${ }^{17}$ Rhodopis apparently remained independent and stayed in Naucratis, while the embarrassment caused by Doricha would suggest a closer or more lasting association. This problem agitated intellectuals already in antiquity. Alan Lloyd suggests that Rhodopis was Doricha's nickname. ${ }^{18}$ Would a person's nickname rather than her real name be inscribed on her dedication in Delphi? Would Herodotus not have mentioned her real name as well? Was Sappho unhappy because her brother had involved himself too deeply with a hetaira? Unlikely. Because he had brought or was about to bring one home from Naucratis and was too obvious about it? Perhaps. Because he had squandered his gains from his wine trade or even his patrimony on buying the liberty of a hetaira? Perhaps. Or was Doricha just one of several problems that burdened Sappho's brother (and thus herself as well)? We simply do not know.

Ultimately, there is no obvious reason to doubt the historicity of individual items in the story: the fame of Rhodopis and/or Doricha, beautiful hetairai in Naucratis, a place famous for its beautiful hetairai; her dedication in Delphi; the

16 Fr. 15 Campbell: ' ... (may he atone for his past mistakes?) ... Cypris, and may she find you very harsh; and may she, Doricha, not boast, telling how he came the second time to a longed-for love'. Trans. Campbell (1982a). On the interpretation of these two poems, see Page (1955) 45-51. For other possible readings of these lines, see the contributions to this volume by Lardinois and Lidov (ch. 3 ).

17 Ancient comments on Rhodopis and Doricha: test. 252, and test. 15 and 16 Campbell (the latter, Ov. Her. 15.63-70, 117-120, may offer the best clues if Ovid drew closely on Sappho's poetry), and the sources mentioned in test. 209 and 254. See also Lloyd (1975-1988) 3.86. On Doricha in frs. 3 and 7: Campbell (1982a) ad loc; Ferrari (2014) 10; in fr. 9: Burris, Fish, and Obbink (2014) 16; see also Lardinois' contribution to this volume.

18 Posidippus is quoted by Ath. $13.596 \mathrm{~b}-\mathrm{d}$, who insists that Rhodopis and Doricha were different women and Herodotus simply confused them. Nickname: Lloyd (as in n. 17 above). For other references: Obbink (2014b) $32 \mathrm{n}$. 1. On these names and possible traditions behind them, see now also Nagy (2015a), (2015c). One of the possibilities mentioned below for explaining Sappho's criticism of her brother (bringing home a hetaira from Naucratis) perhaps receives some support from Obbink's suggestion (in ch. 9 of this volume) of an erotic double entendre in the Brothers Poem: 'full ship' (line 6 [2]) could possibly be understood metaphorically as a "ship with his lover on board." 
travel(s) of Charaxos to Egypt (for whatever purposes, including possibly profits from wine trade), and Sappho's angry, mocking, or simply deeply concerned rebuke of her brother (whatever its reasons and its distortion in poetry). But we have absolutely no certainty that there is any more historical truth in the connection between Sappho, Charaxos and Rhodopis, as Herodotus relates it, than there is in Rhodopis' sponsorship of Mykerinos' pyramid. Moreover, those who consider autobiographical elements in archaic Greek poetry generic rather than specific will hesitate to rely on scattered remarks in Sappho's extant poetry about Charaxos (if it is he) and Doricha to reconstruct actual relationships among her family. As Kurke puts it, Herodotus' 'extraordinary passage reads like an ancient "Lives of the Rich and Famous" ... This titillating quality of the narrative has led scholars to read it very much at face value, and yet, it is precisely the uncritical circulation of stories around celebrities that Herodotus is here debunking.. 19

So much for the state of affairs before publication of the new poem which Dirk Obbink calls the "Brothers Poem." ${ }^{20}$ What does this new evidence change? From my perspective, the most important positive change is that we now have the name of Charaxos attested in Sappho's own poetry, together with confirmation that it is indeed this brother about whose safe return she has been worrying. I quote a little more than the first two complete stanzas in Christopher Pelling's translation:21

Oh, not again-'Charaxus has arrived!

His ship was full'! Well, that's for Zeus

And all the other gods to know.

Don't think of that,

19 The beauty of the hetairai of Naucratis: Ath. 13.596b, d. Generic nature of autobiographical references in archaic poetry: Nagy (199ob) ch. 3. Stories around celebrities: Kurke (1999) 177. Among others, Lardinois (last section) and Stehle in their contributions to this volume also take the brothers as "types" or, if they were real, as endowed with traits of general applicability that made them useful as 'exempla that addressed a number of anxieties that haunted ancient Greek families' (Lardinois). From a different perspective, the comparison with certain genres of painting, Peponi's contribution to this volume, discussing Sappho's experimentation with a "poetics of the familial," illuminates the same issue in very interesting ways.

20 Obbink (2014a), (2014b). For a fuller reconstruction of the poem, see now Obbink, ch. 1 in this volume.

21 Lines $1-9$ ( $5^{-13}$ in Obbink's edition, ch. 1 of this volume); the translation is in Obbink (2014a) and in Pelling and Wyke (2014) 41-42. 
But tell me, 'go and pour out many prayers

To Hera, and beseech the queen

That Charaxos should bring his ship back home

Safely to port,

And find us sound and healthy'

A second important confirmation is that Sappho's concerns extend also to her younger brother Larichos; she prays that he may 'lift up his head' and 'one day be a man', thus turning her worries to joy.22

But, again from my particular and very limited perspective, what is not in this new poem is equally important. It mentions neither Doricha nor Rhodopis, neither the place from which Charaxos is expected to return nor the nature of his ship's load. It says nothing about his activities abroad, about what he did with his money, about a delay and its possible reasons, or about what his return with a fully loaded ship (or even without it) would mean for his sister and family. Sappho does not criticize or blame her brother, she simply worries about his safe return. Overlaps and connections with the other poems I mentioned before (and yet others) are unmistakable, and thus it is tempting to read such connections into this poem (a temptation to which Obbink himself is not immune), but they are not explicit. Unfortunately, since few doubted before that Charaxos was the brother about whom Sappho worries in her poems, the new text does hardly anything to confirm Herodotus' story with which I began. ${ }^{23}$

Fortunately, for my present purpose only one of the story's components matters: Charaxos' travels to and sojourns in Egypt. Precisely because he was not a famous person, no poet or lawgiver, and because Herodotus mentions him only in passing, as a "supporting actor" in another figure's drama, this aspect of

22 Ibid. last stanza. For interpretations of Larichos' role in the poem, see again the contributions of Lardinois and Stehle to this volume.

23 By contrast, Obbink (2014b) 32 writes: 'We quite simply have had no clue, up until now, as to the kind of information, or its source, that could have given rise to Herodotus' story in a way that his fifth century Athenian audience might have found credible. A newly uncovered papyrus changes that.' (And besides, why single out Herodotus' Athenian audience?) Lidov (2004) was among the few who doubted the presence of Charaxos' name in Sappho's poetry. For the importance of the additions to fr. 5 in the present context, see Lardinois' contribution to this volume: references to brother and sister in this poem are now confirmed, and the poem may contain a word play on Charaxos' name (see Burris, Fish, and Obbink [2014] 24). 
the story may well be historical. If it is - and in the continuation of my chapter I will assume that it is - he would be one of few elite Greeks we know by name who spent time in Egypt and returned to their home town (at least, according to Herodotus he did). Why is this important?

\section{Charaxos and "High-Flying" Adventurers: Cultural Interaction between Greece and the Ancient Near East}

By now, we know a great deal about cultural interactions between the ancient Near East and the archaic Greek world, about the broad range of cultural (including intellectual) stimuli the Greeks absorbed in this formative period of their culture. ${ }^{24}$ Unfortunately, research on this topic, which interests me especially from the perspective of early Greek political thinking, ${ }^{25}$ is still handicapped by serious limitations. For example, instead of "influence," which implies a one-way path from the south and east to the north and west of the Mediterranean, we should rather think of cultural interactions, directly, indirectly, and through a "cultural koine" in the eastern Mediterranean. ${ }^{26}$ Even genuine foreign influences were not integrated mechanically into Greek culture. Rather, they were adapted to local conditions and needs, and thus transformed, slightly or massively, depending on many factors. The complexity of such transformation, I suggest, corresponded to the complexity of the issue involved: it was especially high when customs, institutions, and ways of thinking were involved that affected the community as a whole.

The largest and most crucial Greek institution, of course, was the polis itself. Some scholars have suggested that the Greeks imported the polis, via the Phoenicians, from the Ancient Near East. This is highly implausibleeven if it remains possible that the early Greeks profited from other kinds of impulses in the social and political spheres, especially from ideas that might have helped them resolve crises and social conflicts. ${ }^{27}$ Then there is the question of transmission. Who were the carriers of such impulses? Burkert suggests

24 On ancient Near Eastern influences on Greek culture in general, see, e.g., Burkert (1992), (2004); Morris (1992); West (1997).

25 Near Eastern influences on early Greek political thought in particular: Raaflaub (2000) esp. 50-57; (2009).

26 Eastern Mediterranean cultural koinē: this topic is in urgent need of systematic treatment; for now, see, e.g., Sherrat and Sherratt (1993); Fantalkin (2006); Matthäus et al. (2011).

27 On the polis and its emergence, see, e.g., Hansen (1993) chs. 1-2; (2006). The polis as an eastern import: Gschnitzer (1988); Bernal (1993); contra: Raaflaub (2004c). 
migrant workers, who were not integrated into the local oikoi and thus called dèmiourgoi, such as skilled craftsmen, doctors, seers, and singers. Some of these certainly came from abroad; some, like Phoenician silver- or bronze-smiths, settled in Greek villages. Even so, they were metanastai, alien residents, and as such in a precarious position, however much their work might be admired and sought after. One might also think of traders, whether Greeks or the "Sidonians" singled out by Homer. ${ }^{28}$ Most of these were low-status persons. Greeks were eager to acquire their goods; specialists might be happy to adopt their knowledge and skills. This accounts for many foreign impulses in Greek material culture, crafts, technology, and art. Things were definitely different when it came to social and political customs and institutions, in which persons of higher status (independent farmers and elites) had a stake. Free and proud citizens of emerging Greek poleis, I suggest, might not have been interested in what a lowly demiourgos or trader (especially a foreigner) had to say on foreign customs and institutions, let alone in such a person's advice on how the polis should be run.

But they might listen if a fellow citizen of a noble family returned to his hometown after years of traveling, living, or serving in a foreign country, and perhaps brought back an impressive amount of wealth. ${ }^{29}$ An early example is "Odysseus the Cretan," the bastard son of a nobleman, who was shunned by his half-brothers, loved fighting but not labor in house and field, and gained great wealth by undertaking nine raids to Egypt, thus becoming a respected citizen and claiming a wife from a good family. ${ }^{30}$ Herodotus tells us about Kolaios of Samos who was on a trading trip to Egypt when he was blown westward by a storm and became the first Greek to reach Tartessos; he came home with the greatest profit ever reliably recorded. His tithe to Hera of Samos, a huge and magnificent monument, cost six talents. Overall, though, Herodotus says, his wealth was dwarfed by that of Sostratos of Aegina: 'it's impossible that anybody can compete with him!' Sostratos exported beautiful Greek pots

28 Dēmiourgoi, metanastai: Qviller (1980); Gschnitzer (1981) 29, 33-34. Migrant workers: Burkert (1992) ch. 1. Trade and traders (Phoenician and Greek): Bravo (1977); Mele (1979); Garnsey et al. (1983); Latacz (1990); Patzek (1996); Donlan (1997) 651-654; Tandy (1997) 62-75. Craftsmen: Hoffman (1997).

29 Elite Greeks abroad: the evidence is collected and traced back at least to the late 8th century in Raaflaub (2004a). On the role of such men in their Greek communities: Haider (2004) esp. 452-453. For discussion of "contact zones," including supra-regional sanctuaries, where Greek and foreign elites had opportunities to meet, see Ulf (2009) with Raaflaub (2013a) 373-379.

$30 \quad$ Odysseus "the Cretan": Od. 14.199-320, esp. 200-234 (raiding Egypt!). 
(and, no doubt primarily, their contents) to Etruria; we have numerous samples with his so signature. An anchor he dedicated to Apollo of Aegina was found at Gravisca, the port of Tarquinii. This is the group of high-flying adventurers within which Charaxos moved, with whom he played and competed. His bid for Rhodopis, if authentic, may have something to do with such competition. ${ }^{31}$

Herodotus tells stories of many more men of this type who roamed the Mediterranean and traversed adjacent countries not only as merchants on a grand scale but as colonizers, adventurers, and raiders, or as mercenary officers or generals. Near Eastern and Egyptian evidence amply confirms their existence and adds yet other categories of men who served in foreign employment as "high-end specialists" of various kinds (architects, sculptors, engineers, shipwrights, physicians, or seers). Some left dedications in Greek sanctuaries, including one Pedon, son of Amphinnes, who rose from mercenary in Egypt to administrative official and dedicated in Priene a statue in Egpytian style with an inscription attesting that Psammetichus I had honored him for his outstanding service (aristeia) with a golden crown and a polis (that is, probably, entrusted him with leadership in a settlement). Another, Euthykratides of Naxos, dedicated in the late seventh century in Delphi a kouros standing on the backs of men; probably returning from foreign service, he used an Egyptian royal motif to underscore his importance. ${ }^{32}$ Both these men undoubtedly had spent a large part of their lives in Egypt and knew it well.

This allows us to make another connection with Lesbos. Alcaeus himself may have entered foreign service while he was in exile. His brother certainly did. Strabo writes: 'Mytilene produced famous men: in olden times Pittacus ... and the poet Alcaeus and his brother Antimenidas, who according to Alcaeus performed a great feat while fighting as ally of the Babylonians, and rescued them from trouble by killing a warrior who, he says, was only one palm's breadth short of five royal cubits' (13.2.3; trans. Campbell). An extant fragment of Alcaeus may refer to Antimenidas: 'You have come from the ends of the earth with the hilt of your sword ivory bound with gold' (fr. 350). According to a scholiast, Antimenidas performed this exploit when Nebuchadnezzar campaigned

31 Kolaios of Samos, Sostratos of Aegina: Hdt. 4.152; see Möller (2000) $5^{6}$ with documentation. What might have been, from Sappho's perspective, 'self-destructive passion' (Nagy [2015c]) thus probably was, from Charaxos' perspective, a triumphant success.

Near Eastern testimonies to Greeks abroad: e.g., Pedon: Haider (1996) 100-101; (2004) 450451 (with bibliog. and fig. 3 on p. 483); Euthykratides of Naxos: Haider (1996) 113. For further bibliography, see Raaflaub (2004a). 
against Askalon in 604 BCE. ${ }^{33}$ Presumably, Antimenidas had spent some time in Mesopotamia and brought back much more than a precious sword.

If we look for men who could report with authority about foreign customs, social concepts, or political ideas, and to whom his fellow nobles would listen, I suggest, we will find them among these types of persons, including Charaxos himself.

\section{Charaxos' Trade}

But what about Charaxos' trade? We know that the exchange of high-end merchandise $^{34}$ flourished across the Mediterranean and that elite Greeks engaged in this type of business, both occasionally, to finance a trip abroad for which they might have all kinds of motives, and more consistently, though never really professionally. ${ }^{35}$ This type of trade was compatible with Greek elite values. Hesiod already is fully aware of both the immense gains promised by such trading ventures and the great dangers involved: he warns not to put all one's eggs in one basket. ${ }^{36}$ High-quality Greek wine certainly was widely desired, and Lesbian wine had an excellent reputation. ${ }^{37}$ That Charaxos shipped Lesbian wine to Egypt is thus not surprising: presumably to Naucratis, but not necessarily for consumption only there.

By his time the 'bronzemen' (presumably Greek or Carian raiders wearing hoplite equipment) who had landed in Egypt and then entered the service of Psammetichus I, had, so to speak, multiplied. Just a little later, 30,00o of them were reported to live in Egypt in various settlements, serving the Pharaoh, helping him to fight his wars, and even assuming administrative functions (as Pedon did). Some of them returned home (we met a couple of them); others married Egyptian women and produced sons with mixed names and grandsons with

33 Alcaeus in foreign service: Kaplan (2002) 234-235. For the context of Antimenidas' feat: Quinn (1961); Braun (1982a) 22.

34 To avoid the problematic term "luxury goods" because what for one person or place is a luxury is not for others (Foxhall [1998] 299-300).

35 On trade with high-end merchandise: Foxhall (1998); on early Greek maritime trade, see also Reed (2003), and see n. 28 above.

36 Hes. Op. 629-632, 643-645, 689-694.

37 Clinkenbeard (1982) collects the evidence for Lesbian wine export to Naucratis and lists the statements in praise of this wine by Greek comic poets and others, quoted by Athenaeus of Naucratis (Deipnosophists 1.28e-f, 29b; 3.92e; 13.598c); I thank Deborah Boedeker for these references. 
fully Egyptian names. Funeral inscriptions attest to this process of assimilation. To their communications, Herodotus emphasizes, those back home owed a vastly increased knowledge of Egypt. ${ }^{38}$ I suggest that the elite among this large Greek or semi-Greek population, and of the partly Hellenized Egyptian population surrounding them, would have been a target of Greek traders in high-end merchandise-directly or, perhaps more likely, given Egyptian suspicion of foreigners, indirectly through middlemen in Naucratis. ${ }^{39}$ If so, this would have massively increased the bulk of trade.

Archaeology helps us trace some of this trade: containers used to transport wine, and pots and cups specifically designed to mixing and drinking wine, have been excavated on land and in ancient shipwrecks all over the Mediterranean..$^{40}$ The former attest to the trade networks, the latter to the distribution of the culture of drinking wine. Amphorae of Lesbian origin are prominent among these: finds range from Sicily and Etruria to the Black Sea and the southern Levant on the way to Egypt. Naucratis has yielded substantial numbers of elegant early sixth-century drinking vessels. But we should refrain from thinking that wine was the only trade good; diversification was important already then. Other goods exported to Egypt might have included agricultural products, textiles, metals (also well-attested in ship-wrecks) and silver, apart from the intriguing Madonna Lily that was then cultivated in Egypt as an ingredient in perfumes. ${ }^{41}$

What does all this mean for Charaxos? Even if we cannot know, there clearly was in Egypt a consistent demand for high-quality wine. This suggests that a direct trading link might have existed between Lesbos (and other places producing such wine) and Naucratis that satisfied this need; wine producers on Lesbos would have adapted to this, and elite merchants like Charaxos would have exploited the opportunity. ${ }^{42} \mathrm{He}$ might have banked his fortune on a big

38 Bronzemen: Hdt. 2.152, 154. 30,000 under Apries (589-57о вС ): 2.163. On the large Greek colony in Egypt, see Braun (1982b); Haider (1996), (2004); Möller (2000) 32-38. On early Egyptian-Aegean relations: Helck (1995).

39 On Egyptian concerns about foreigners, see Moers (2010).

40 Distribution of Lesbian amphorae: Dupont (1998) 156-163; more generally: Grace (1970); Garlan (1983); Snodgrass (1983); Whitbread (1995). Attic drinking vessels: Osborne (1996). Shipwrecks: Parker (1992).

41 On archaeological evidence concerning archaic trade with Egypt, see e.g. Krotscheck (2008); Fantalkin and Tal (2010). Especially on Naucratis and its trading community: Möller (2000); see also Villing and Schlotzhauer (2006). Other goods and "cross-trade": Foxhall (1998) who mentions the Madonna Lily (Huxley [1977]).

I draw here on Osborne's excellent article (1996). 
shipment of wine or, as Hesiod advised, been cautious enough to invest in smaller shipments, taking other goods along too. His sister's anxiety may or may not suggest the former. On the way back, he certainly did not sail emptywe remember the hope that he would return with a full ship. He might have carried whatever was in need and popular at home, and promised gain: papyrus products (sails, ropes, paper), culinary delicacies, spice (like natron), durum grain (popular for bread), other types of wine (for instance, from Byblos which we know was popular in Greece), and perhaps slaves. ${ }^{43}$ Unlike professional traders who stopped at every port, he would have sailed with purpose, stopping only at prime destinations, and as directly and quickly as possible.

\section{Pittacus, Tyranny, and Greek "Straighteners"}

With his presumably extensive knowledge of Egypt (and perhaps other parts of the Near East), Charaxos would have been a respectable source for the transmission of political ideas. Yet for some of these one did not have to go all the way to Mesopotamia or Egypt. To Greeks living on the Anatolian coast and the large islands near it, such as Lesbos, the customs and life style of the Lydian elite were closely familiar, and it is no accident that archaic poets, not least Sappho and Alcaeus, were intensely interested in the positive and negative aspects of eastern wealth and luxury. ${ }^{44}$ Lydia was also the home of Gyges, famous for being exposed to hard choices: having been forced by his king to watch his queen undress, he could only survive by marrying her, murdering her husband, and usurping his rule. It is this man whom Archilochus characterizes, for the first time in extant Greek literature, as "tyrant" (tyrannos). ${ }^{45}$

Like many other poleis at the time, Mytilene itself suffered from a long and turbulent history of fights between tyrants and elite factions resisting them. The struggles going on in Sappho's time pitted Alcaeus' group (among others,

43 Returning with a full ship: Brother's poem, lines 1-2 (at n. 21 above) or $5^{-6}$ in the new edition (Obbink, ch. 1 in this volume). Papyrus sails and ropes: Hermippus, Phormophoroi fr. $63 P C G$, quoted by Ath. 1.27-28. Natron (with a surprising range of uses that are significant in Sappho's context): suggested by Ewen Bowie in his contribution to this volume. Other goods imported from Egypt (durum grain) and special wines (Byblos: Hesiod, $O p$. 589; cf. Ismaros: Archil. fr. 2): Foxhall (1998).

44 Kurke (1992).

45 Gyges and the wife of Candaules: Hdt. 1.7-14; for brief comments and bibliography, see Asheri et al. (2007) 81-82; tyrannos: Archil. frs. 19 and 23. 
no doubt) against various tyrants, including finally Pittacus. ${ }^{46}$ We know little, if anything, I think, beyond the vaguest allusions, about how Sappho herself and her brothers thought about and were involved in these "troubles" but, since they belonged among the elite of Mytilene, these events must have played a significant role in their lives. Nor do we know whether later traditions about a period of exile in Sappho's own life, if they are trustworthy, were in any way connected with these troubles. Nor again can we tell, although the possibility seems obvious, whether these "troubles" had anything to do with Charaxos' decision to seek his fortunes abroad ${ }^{47}$ But this brings up the notion of tyranny, and it is worth a final consideration.

The word tyrannos may well be of Lydian origin, and scholars have long speculated about an Anatolian or Near Eastern origin of the institution as well, presenting, in some cases, elaborate arguments to defend this hypothesis. For several reasons-including especially the Greek use of the word tyrannos, the nature of the institution it designated, and the character of the historical tradition that has preserved its memory-I do not consider such arguments plausible. ${ }^{48}$ Not least, the phenomenon the Greeks described as tyranny defies a single definition: tyrannos was an "umbrella term" under which a great variety of phenomena connected with sole rule or authority were subsumed. In particular, the third "super-famous" individual of Sappho's time, Pittacus, though generally considered a "tyrant" and fiercely attacked as such by his aristocratic contemporaries and rivals, was the stark opposite of an oppressive despot-let alone one with an oriental pedigree. Rather, though holding sole power, he was a leading representative of a much milder version of "tyranny."

In the seventh and sixth century, the Greeks developed the method of bestowing autocratic power on individual 'straighteners' (katartistēres) or 'mediators' (aisymnètai) — in modern scholarship they are often called 'lawgivers'as an ingenious instrument to resolve serious social and political crises and prevent the disintegration of communities. This is, I think, a genuine Greek creation. Aristotle identifies this form of "elected tyranny," non-hereditary and

46 "Troubles" in Mytilene: see relevant sections in Page (1955); Rösler (1980); Podlecki (1984): ch. 3 ; see also n. 49 below on Pittacus.

47 On Sappho and her exile, see Page (1955) 130-131; Podlecki (1984) 83; West 2014: 3. More generally, on Sappho in her social and poetic context, Ferrari 2010 is crucial. In her contribution to this volume, Stehle discusses the elite background of Sappho's family. In his contribution, Lardinois surveys the biographical traditions and (in his commentary on line 13) mentions the possibility that the troubles worrying the interlocutors in the Brothers Poem could be political in nature.

See the appendix below. 
bound to the law, with the institution of aisymnēteia, which existed also as an elected extraordinary office (such as both Pittacus and Solon held it). Like Solon, Pittacus was a lawgiver and known as one of the Seven Sages who were connected with Delphi and its advocacy of moderation. No wonder that the citizens of Mytilene, which Alcaeus called 'that gutless, ill-starred polis', confronted with the detrimental impact of endless fights among elite factions, established him as a mediator and straightener and thus, from the perspective of the disempowered aristocratic leaders, a tyrant, 'all of them loud in his praise. ${ }^{49}$ Again, one wonders what Sappho thought. ${ }^{50}$

\section{Appendix: Near Eastern Origins of Greek Tyranny?}

Efforts have often been made to show that Greek tyranny was derived from Near Eastern forms of autocratic rule. Martin West, for example, thinks that early Iron Age Greek kingship 'reflects a pattern that is essentially that of a Near Eastern monarchy'. John Davies, too, emphasizes that 'forms of monarchy closely comparable to those well attested in the Phoenician cities' were widespread in Archaic Greece, including 'the various "tyrant" regimes of Ionia, the Aegean, and central Greece'. Pace Davies, I believe strongly that the differences between archaic Greek phenomena of sole rule and Phoenician or Near Eastern forms of kingship are more significant than the correspondences. Similarities in appearance do not necessarily signify identity in nature, let alone derivation or borrowing. A leader's or king's social, religious, and political roles

49 On Pittacus, Arist. Pol. 1285a35-b1; Alc. fr. 348; de Libero (1996) 314-328. On aisymnētai: Arist. Pol. 1285a30-33; see Schütrumpf (1991) 536-537, 542-543; Romer (1982); Meier (1990) 40-52; (2011) ch. 21; Faraguna (2001); Wallace (2009). On Pittacus as lawgiver: Hölkeskamp (1999) 219-226. On the Seven Sages: Snell (1971); Rösler (1991); Martin (1993).

$5^{\circ}$ I would like to draw attention here to a late 4th-century inscription ( $S E G$ 36: 750; Rhodes and Osborne [2003] no. 85A) that is obviously situated in a time of civil unrest, connects Hera (supplicated in the Brother's poem; see Boedeker's contribution to this volume) intimately with Zeus whose epithets include not only Hêraios and Basilēios but also Homonoios (husband of Hera, king, and protector or restorer of concord), and in addition appeals specifically to Homonoia, Dikē, and Epiteleia (Concord, Justice, and Accomplisher of all good things); see Delforge and Pironti (2014). Although the personification

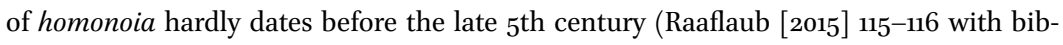
liog.), allusions in both Alcaeus and Sappho and archaeological finds date the pan-Lesbian sanctuary of Messon firmly to the archaic period (see again Boedeker, this volume), and it seems plausible to assume that it played a mediating and unifying role already in "the troubles" of the poets' time. 
remain embedded in the conditions that characterize his specific society. Quite rightly, therefore, Davies continues: 'This is not to suggest precise knowledgeable borrowings on the part of Greeks so much as the sort of awareness of institutions in Assyria or Phoenicia or Egypt which mercenaries, craftsmen, and emporoi will inevitably have gained and brought back.51 I use this opportunity to re-examine this question, although, in the present context, I can only do this very briefly.

Archilochus, perhaps reflecting Lydian usage, applied the word tyrannos to Gyges, who usurped power around 685 BCE. ${ }^{2}$ Gyges maintained good relations with Psammetichus I who consolidated his power in Egypt in the 650s, around the same time as Cypselus established his in Corinth, supposedly by armed usurpation. Gyges' offerings to Delphi were stored in Cypselus' treasury, and Cypselus' grandson was named Psammetichus. ${ }^{53}$ Clearly, networks existed among eastern monarchs into which Greek tyrants fit easily. It is no doubt possible that Psammetichus and Cypselus were inspired by Gyges' usurpation, or Gyges by that of Sargon II of Assyria. After all, usurpations had been common in ancient West Asia for millennia; they were typical of a world of competing dynasts, city-states, and empires. But I consider it very uncertain that, as has been claimed, Cypselus and later Greek tyrants all used the same methods to assume and control power and that they learned these methods from the east. ${ }^{54}$ I offer three main reasons to support my doubts.

First, according to extant archaic Greek evidence, the word tyrannos served as a label rather than a title. ${ }^{55}$ It had positive connotations for those aristocrats who dreamed of attaining tyranny themselves, but was negative in the view of those whom, like Alcaeus, the tyrant's monopolization of rule excluded from their traditional share of power, or who, like Solon, were primarily concerned with the communal good. ${ }^{56} \mathrm{~A}$ functional distinction between basileia as a legit-

51 On Greek and eastern kingship and tyranny: West (1997) 14-19, 132-137 (on analogies in the ideology of kingship); Davies (1997) 33-34; Morris (2003). Tyranny as an eastern import: Hegyi (1965); Drews (1972); Fadinger (1993). See $n$. 45 above. For Lydian origin of the word (and a close relationship to Etruscan türan ['lord, master' vel sim]), see documentation in Fadinger (1993) 265 n. 8.

53 For Gyges, Psammetichus, and Cypselus, see the sources listed in Fadinger (1993) 265-266; Drews (1972).

54 For such claims, see the authors listed in $n .5^{1}$ above, esp. Fadinger (1993).

55 Evidence: Berve (1967) 1.3-6 with references in 2.517-518.

56 The former esp. in Archil. fr. 19; Solon fr. 33. Solon's refusal: fr. 32 . For discussion of this antinomy, see Connor (1977). I have contested the conclusions Connor draws for fifthcentury politics: Raaflaub (2003) 77-81. 
imate and good form of monarchy and tyrannis as an illegitimate and bad type did not prevail before the late fifth century. This negative image was shaped by a few notorious cases of oppressive and cruel tyrants, while the sources also preserve the memory of tyrants as defenders of justice and the demos against elite violence and abuses, as paragons of wisdom, or even as responsible for bringing back of an "Age of Kronos." 57 Tyranny thus is an umbrella term, encompassing various forms of sole rule that share some basic elements (especially the monopolization of power by an elite person at the expense of his fellow aristocrats) but differ in origins and characteristics. ${ }^{58} \mathrm{It}$ is only from a much later perspective of historical interpretation (by Herodotus) or theoretical categorization (by Aristotle) that tyranny became a more homogeneous phenomenon with a wider range of specific and shared characteristics. And it is only from such late perspectives that Near Eastern influence became a plausible assumption.

Second, for archaic tyranny, Herodotus is our earliest and most detailed source. But Herodotus wrote long after the events he describes and with a specific interpretive purpose. He drew largely on oral tradition. By the time he collected his material, roughly two hundred years had passed since Cypselus' usurpation, and the threshold of living memory coincided roughly with Pisistratus' assumption of power in 546. Most tyrants were active much earlier, which cautions us against taking at face value what Herodotus and later sources (such as Aristotle, Plutarch, and Pausanias) tell us about them. ${ }^{59}$ Moreover, memories were constantly reshaped by recent experiences, changing political perspectives, and new "myths" - in Athens, the tyrannicide of 514, Hippias' oppressive rule in its aftermath, and the Persian Wars, in which the Greeks were confronted with an absolute ruler whom, lacking other models, they equated with a "super-tyrant."60 These experiences most likely also tainted their view

57 Distinction from basileia: Parker (1998); see also Barceló (1993). Positive conception of the role of tyrants: McGlew (1993); Bassi (1998) 144-191; Kurke (1999) 67-100; Lewis (2009). Age of Kronos: Arist. Ath. Pol. 16.7 with comments by Rhodes (1981) 217-218.

$5^{8} \quad$ Kinzl (1977); cf. generally Berve (1954); Pleket (1969); Parker (1996); Lewis (2009) esp. 8-11; Stein-Hölkeskamp (2009).

59 Oral memory: Vansina (1985); Ungern-Sternberg and Reinau (1988). On Herodotus and Athenian history: Raaflaub (1988); Cobet (1988); Thomas (1989). Osborne (1989) $313 \mathrm{em}$ phasizes the dearth of memories in Athens about events of the seventh century. Herodotus and early tyranny: Stahl (1983). Critical analyses of the tyranny of Pisistratus and his sons: Stahl (1987); Welwei (1992) 229-265; Sancisi-Weerdenburg (2000); Lavelle (2005).

$60 \quad$ See Lavelle (1993); Thomas (1989); Forsdyke (1999); also Raaflaub (2004b) 100-101 with bibliog. 
of early Greek tyrants: many of the specifically "tyrannical" aspects of these figures may thus be influenced by Near Eastern patterns-not because they were identical but because later Greek observers, thinking they perceived analogies, retrojected such patterns upon these figures and made them look identical. 61

Moreover, the earliest historians wrote not only in conditions that differed starkly from those in the seventh and sixth centuries but also with a concept of history that differs essentially from ours. To the most serious and responsible among them (especially Herodotus and Thucydides), history was important primarily because and insofar as it was meaningful to the present. Past and present stood in a dialectical relationship that was determined by the needs and concerns of the present. This, combined with the difficulties of knowing what had really happened in the more distant past, gave the historian some liberty - I would even say, it compelled him — to shape history in a way that emphasized those aspects that would attract the attention of their public and stimulate them to think about the present. ${ }^{62}$ Confronted in his time not least by the problems caused by the contention of the two Greek "superpowers" for supremacy and the oppressive rule of a polis tyrannos, Herodotus used inter alia the phenomena of imperialism and tyranny to realize his purpose of making past history relevant to the present. As Carolyn Dewald has shown, he employs as an interpretive tool a homogenizing analytical template of tyranny that recurs throughout the work. ${ }^{63}$ Much of this "tyrannical template" concerns persons and events located in the sphere of "mythical memory" (that is, as suggested above, before 550) and even outside of Greece, and it both draws on and affects his portrait of eastern monarchs as well.

Hence it is a priori likely that in Herodotus' depiction of Greek tyrants we are dealing not with one-sided eastern influence on a factual-historical level but with a much more complex problem that is situated primarily on an intellectual-interpretive level. François Hartog suggests that the barbarian 'king and the tyrant are two of a kind. Each provides a mirror image for the other ... At the intersection of these two images the representation of despotic power is constructed'. Elaborating on this, Kurke says: 'all Eastern monarchs in

\footnotetext{
61 Integration of Persian models into the context of Greek tyranny: Heuss (1971) 12-17 ([1995] 114-119).

62 Strasburger (1955); Fornara (1971); Raaflaub (1987), (2002), (2010), (2013b); Kurke (1999); Dewald (2003).

63 Dewald (2003). Herodotus and imperialism: Raaflaub (2002). For earlier discussions of Herodotus' representation of tyranny, see Waters (1971); Barceló (1993) 149-177.
} 
Herodotus serve a double function - they represent the Other, but they simultaneously furnish Herodotus and his audience with paradigms for conceptualizing the modalities of Greek tyranny' ${ }^{64}$

Hence, even if Herodotus had some good information on the early Greek tyrants, we do not know when he did, we cannot distinguish with any certainty between "mythical" and "historical" information and his own dramatic elaboration and purposeful interpretation, and we have to credit his authorship with traces of the "tyrannical template." While we can somewhat control his narrative on eastern monarchs because we have reliable information in Near Eastern sources, ${ }^{65}$ for early Greek tyranny we mostly lack independent evidence. As a consequence, Herodotus needs to be virtually eliminated as a source for comparison between eastern monarchy and Greek tyranny, let alone for the question of influences of the former on the latter.

Those who argue for such influences usually fail to consider any of these issues. Often they simply assume that Herodotus reports historical facts throughout. Moreover, in such arguments a specific chapter in Aristotle's Politics plays an important role. ${ }^{66}$ Discussing the methods tyrants typically use to secure their power, this passage is a piece of systematic theoretical analysis that conflates phenomena from various periods and areas and seems to draw heavily on the example of Dionysius I of Syracuse. ${ }^{67}$ Dionysius lived around two hundred years after his archaic predecessors; he was atypical in several ways and established his rule in conditions that differed massively from those in archaic Greece. By his time, the Greek world was thoroughly familiar with autocratic Persian monarchy, and he may indeed have drawn on that model. Aristotle knew the methods of both Dionysius' rule and that of the Persian kings and 'other barbarians'. At the same time, as Schütrumpf and Gehrke observe in their commentary, the traditions Aristotle mentions probably concern a firmly established typology of tyranny that was connected especially with the name of Periander; but, in view of undoubtable elaboration based on later experiences, it is impossible to know how much of this is authentic material that can be attributed to the historical Periander. ${ }^{68}$ Clearly, all this offers an unreliable

64 Hartog (1988) 322-339 (quote: 324-325); Kurke (1999) 70, cf. 93. See also, on parallels between the Herodotean portraits of Pisistratus and Amasis, Bassi (1998) 145-191.

65 See, for a start, Lanfranchi and Rollinger (2010).

66 Arist. Pol. 5.11.1313a34-b32, exploited esp. by Fadinger (1993); on Aristotle's chapter, see Heuss (1971); Meister (1977); Schütrumpf and Gehrke (1996).

67 On the tyranny of Dionysius I: e.g., Berve (1967) 1.222-26o, 2.637-656; Sanders (1987); Jordović (2005) 245-266.

68 Arist. Pol. 1313a36-38, b9-10. On Periander, see Hdt. 5.92; Stahl (1983). Schütrumpf and 
basis for claiming an oriental-style monarchy not only in early fourth-century Syracuse but in sixth-century Athens and even earlier in Corinth.

Finally, to mention the obvious without entering into a detailed discussion, upon closer inspection Greek tyranny differs markedly from Near Eastern, even Phoenician, models of monarchy. All Near Eastern monarchies were hereditary by nature, firmly embedded in the institutions of the city or state concerned, and intimately connected with the divine. None of this applies to Greek tyrants whose power was personal and located above and outside the institutions of the polis, failed to gain institutional recognition and permanence, and was secular in nature. ${ }^{69}$

For all these reasons, then, the thesis that Greek tyranny was derived from eastern models remains implausible to me. It is, at any rate, too general and too simple. Greek tyranny as such, that is, the sole rule established by an aristocratic individual who monopolized the power previously shared by his peers, differed and indeed had to differ-structurally, socially, politically, and from the perspective of social mentalities-from comparable institutions in ancient West Asia and Egypt. My sense is that the phenomenon of Greek tyranny as such did not require outside stimuli and can be explained sufficiently within a Greek framework as a result of extreme individual ambition, increasingly fierce elite competition, and increasing social tensions. ${ }^{70}$ Yet Archilochus and Herodotus leave no doubt that Greeks stared with fascination at the Lydian kings, and perhaps far beyond (just as our contemporaries do at royalty), both for their wealth, glamor, and power, and for their (often scandalous) behavior. Hence in the context of elite connections ranging widely beyond the Greek world, knowledge of foreign phenomena may well have stimulated emulation and specific imitation, but mostly in more limited ways: in lifestyle and luxury, rituals and ostentation at court, insignia and paraphernalia of power and

Gehrke (1996) 581 offer important observations on the relationship between Aristotle's own interpretation and existing traditions.

69 Although, of course, Greek tyrants fostered polis-cults and built temples in order to emphasize their patronage and, at least in the case of Athens, highlight the significance of the polis' central place (at the expense of the local centers where their aristocratic rivals' power was rooted); see e.g. Kolb (1977). Pisistratus' scheme of using an allegedly special connection with Athena to gain power in his "second tyranny" has been interpreted in various ways that do not make it necessary to invoke oriental customs: Hdt. 1.6o.3-5; oriental custom: Fadinger (1993) 293-306; (2000); for different explanations, see Connor (1987) 42-47; Blok (2000); Lavelle (2005) 99-107; also Linke (2005).

70 On the nature of Greek tyranny, see e.g. Berve (1954); Pleket (1969); Kinzl (1977), and e.g. Murray (1993) ch. 9; Stein-Hölkeskamp (2009); Meier (2011) ch. 19. 
methods of securing power, policies of sponsoring buildings and culture, the maintenance of far-reaching international connections, and so on. ${ }^{71}$

71 On these aspects, see e.g. Morris (2003), Dewald (2003). It is in this context too, that some of Fadinger's perceptive observations (1993) remain important. 